\title{
Efficacy and Safety of Mycophenolate Mofetil Combined with Low Dose Prednisolone versus Standard Dose of Prednisolone in the Treatment of IgA Nephropathy: A Randomized Controlled Trial
}

Shah Md Zakir Hossain ${ }^{1 *}$, Muhammad Rafiqul Alam², Sk Md Ershad ${ }^{3}$, Tahmeed Hussain ${ }^{4}$, Md. Zayeed Ahsan ${ }^{5}$, Anirban Kishor Singha ${ }^{6}$, Sharmin Akter $^{7}$

${ }^{1}$ Medical Officer, Department of Nephrology, Bangabandhu Sheikh Mujib Medical University, Dhaka, Bangladesh

${ }^{2}$ Professor of Nephrology, Bangabandhu Sheikh Mujib Medical University, Dhaka, Bangladesh

${ }^{3}$ Medical Officer, Directorate General of Health Services, Mohakhali, Dhaka, Bangladesh

${ }^{4}$ Classified Specialist in Medicine (Nephrology), CMH, Dhaka, Bangladesh

${ }^{5}$ Medical officer, Directorate General of Health Services, Mohakhali, Dhaka, Bangladesh

${ }^{6}$ Registrar, Department of Nephrology, Kurmitola General Hospital, Dhaka, Bangladesh

${ }^{7}$ Registrar, Dept of Obstetrics \& Gynecology, Institute of Child \& Mother Health, Matuail, Dhaka, Bangladesh

DOI: $10.36347 /$ sasjm.2021.v07i02.006

| Received: 07.02.2021 | Accepted: 20.02.2021 | Published: 23.02.2021

*Corresponding author: Shah Md Zakir Hossain

Abstract Original Research Article

Introduction: Despite showing varying degree of prevalence rate with geographical variations, IgA nephropathy (IgAN) remains a leading cause for glomerular disease worldwide. Being an auto immune disease, using oral prednisolone for six months has been in practice for long. This paper aims to evaluate the efficacy and safety of mycophenolate mofetil combined with low dose prednisolone versus standard dose of prednisolone in the treatment of IgA nephropathy. Methodology: This was an open label randomized clinical trial conducted for one year during 201819 among newly diagnosed 53 adult patients with IgA nephropathy from department of Nephrology, Bangabandhu Sheikh Mujib Medical University (BSMMU), Dhaka. After enrollment of the study respondents were randomized into two groups and one group was given MMF orally with a dose of $1500 \mathrm{mg}$ /day for consecutive 6 months with Prednisolone $0.5 \mathrm{mg} / \mathrm{kg} /$ day for 2 months and then tapered by $0.1 \mathrm{mg} / \mathrm{kg} / \mathrm{day}$ each month for next 4 months. Another group was given 6 months regimen of oral prednisolone starting with $1.0 \mathrm{mg} / \mathrm{kg} / \mathrm{day}$ for 2 months and then reduced by $0.2 \mathrm{mg} / \mathrm{kg} / \mathrm{day}$ per month for the next 4 months. Patients were monitored at baseline and at subsequent intervals. At the end of $6^{\text {th }}$ month, all the patients were evaluated for outcome measures and adverse effects of the medications. Results and discussion: In group A $38.46 \%$ patients had complete remission, $42.31 \%$ had partial remission and $19.23 \%$ had no remission. In group B, $40.74 \%$ had complete remission, $40.74 \%$ had partial remission and $18.52 \%$ had no remission. No statistically significant difference in remission rate between two groups were found. In regards to potential adverse effects, some variations between the groups have been observed; most frequent adverse effect in group A was infection (23\%). In group B most frequent adverse effect observed was Cushing's syndrome (33\%). Conclusion: Mycophenolate mofetil and low-dose prednisone combined therapy can be considered a reasonable treatment choice for IgA nephropathy. An extended multi-center clinical trial with larger and more diverse study population should give us a better idea on the efficacy and safety of mycophenolate mofetil combined with low dose prednisolone versus standard dose of prednisolone in the treatment of $\operatorname{IgA}$ nephropathy.

Keywords: Prednisolone, Mycophenolate Mofetil, IgA Nephropathy.

Copyright $\left({ }_{0} 2021\right.$ The Author(s): This is an open-access article distributed under the terms of the Creative Commons Attribution 4.0 International License (CC BY-NC 4.0) which permits unrestricted use, distribution, and reproduction in any medium for non-commercial use provided the original author and source are credited.

\section{INTRODUCTION}

$\operatorname{Ig}$ A nephropathy $(\operatorname{IgAN})$ is one of the leading causes of glomerulonephritis in the world that varies in its geographical distribution $[1,2]$. IgAN is found in > $40 \%$ of kidney biopsy specimens obtained for primary glomerulonephritis (GN) in Asia, > 30\% in Europe and $>20 \%$ in United states [3].

The clinical outcome of this disease ranges from asymptomatic hematuria to progressive renal failure and even end stage renal disease (ESRD) [4-6]. Approximately $20-40 \%$ of affected patients reaching 
ESRD within 10-20 years of diagnosis [7, 8]. The pathogenesis of $\operatorname{IgAN}$, although incompletely understood, is recognized as an autoimmune kidney disease. The binding of IgA to putative Fc receptors on the surface of mesangial cells leads to mesangial hypercellularity and production of proinflammatory cytokines. In addition, IgA complexes can indirectly stimulate cell proliferation and mesangial matrix deposition through the activation of complement via the alternative pathway. While mesangial cell hypercellularity and matrix expansion are common in IgA nephropathy, additional glomerular pathology can include endocapillary proliferation, karyorrhexis and cellular crescents [9-11]. IgAN is histopathologically defined by mesangial IgA deposits which are dominant or co-dominant with $\mathrm{IgG}$ or $\mathrm{IgM}$ and variably accompanied by $\mathrm{C} 3$ [12]. KDIGO recommends longterm ACE-I or ARB treatment when proteinuria is greater than $1 \mathrm{~g} /$ day, with up-titration of the drug depending on blood pressure and suggests if proteinuria is between 0.5 to $1 \mathrm{~g} /$ day (in children, between 0.5 to 1 $\mathrm{g} /$ day per $1.73 \mathrm{~m}^{2}$ ). Corticosteroids is suggested to be given with persistent proteinuria greater than $1 \mathrm{~g} /$ day, despite 3-6 months of optimized supportive care (including ACE-I or ARBs and blood pressure control), and GFR greater than $50 \mathrm{ml} / \mathrm{min}$ per $1.73 \mathrm{~m}^{2}$, receive a 6-month course of corticosteroid therapy. Immunosuppressive agents (cyclophosphamide, azathioprine, MMF, cyclosporine) only indicated when there is crescentic IgAN with rapidly deteriorating kidney function [13].

Besides conventional therapy of regular dose of prednisolone for six months, mycophenolate mofetil (MMF) has been suggested to be a promising therapeutic agent in the treatment of $\operatorname{IgAN}[14,15]$. Mycophenolic acid (MPA) is a potent, reversible, and noncompetitive inhibitor of inosine 5-monophosphate dehydrogenase [16, 17]. MPA selectively inhibits the proliferation of $\mathrm{T}$ and $\mathrm{B}$ lymphocytes, the production of antibodies, the generation of cytotoxic $\mathrm{T}$ cells and the recruitment of leukocytes to sites of inflammation. Results from large-scale clinical trials in renal transplantation demonstrated that MMF is a highly effective immunosuppressive drug with an acceptable safety profile ${ }^{18}$. MMF has become one of the standard immunosuppressive agents in many transplant centers and has been successfully used in short-term pilot studies to treat immune-mediated glomerulopathies and systemic immune disorders [14, 19]. The effect of MMF in addition to angiotensin-converting enzyme (ACE) inhibition, combined with other strategies (rigorous blood pressure control, sodium restriction, non-dihydropyridine calcium blockade) that interfere with progressive proteinuria nephropathies has never been studied in humans.

There is, however, also growing experimental evidence that the anti-inflammatory properties of MMF may, by attenuating glomerular and interstitial injury, be beneficial in the treatment of progressive nephropathies [20, 21]. Currently there is no such study on efficacy and safety of this drug regimen in Bangladeshi population exists. So, this paper aims to evaluate the efficacy and safety of MMF combined with low-dose prednisolone versus normal-dose prednisolone in the treatment of IgA nephropathy among Bangladeshi population.

\section{METHODOLOGY}

This was an open label randomized clinical trial conducted for one year during 2018-19 among newly diagnosed (within last six months) 53 adult patients with IgA nephropathy with urinary total protein excretion greater than $1 \mathrm{gm} /$ day from department of Nephrology, Bangabandhu Sheikh Mujib Medical University (BSMMU), Dhaka. Prior to commencement of this study, the research protocol was approved by the Institutional Review Board, BSMMU, Dhaka. The aims and objectives of the study along with its procedure, risk and benefits of this study were explained to the patients in easily understandable local language and then informed consent was taken from each patient. There were rights of withdrawal of participants at any time of thesis work. For the purpose of this study, patients with estimated GFR $<50 \mathrm{ml} / \mathrm{min} / 1.73 \mathrm{~m}^{2}$ body surface area (BSA) were excluded along with crescents involving $\geq 50 \%$ glomeruli in renal histopathology. Pregnant or lactating mother, women of childbearing potential who are not using highly effective contraception, Intolerant to MMF or to any of the excipients and patient with active infection, active malignancy or altered liver function were also excluded from the study. Finally 58 study subjects were enrolled in the study. At first, they were educated about the natural history, pathophysiology, and available treatment options of IgA nephropathy. Then they were thoroughly appraised about the study as well as drug information which included efficacy, safety and cost of MMF and corticosteroid. Patients were treated with ACEI/ARB for 3-6 months; blood pressure target was $<125 / 75 \mathrm{mmHg}$. The patients with persistent proteinuria $>1 \mathrm{~g} /$ day were randomized into two groups.

Statistical analyses were performed by using Statistical Packages for Social Sciences (SPSS) version 25 for Windows. Test statistics used to analyze the data were Chi-square Test, inter group analysis was done by Student " $\mathrm{t}$ ' test (unpaired). $\mathrm{P}$ value $\leq 0.05$ was considered significant.

\section{RESULTS}

Among the 53 respondents, 26 from Group A and 27 from Group B, mean age was 33.67 years and 33.44 years respectively and 33.56 years for the whole study population. Distribution of subjects on the basis of age cluster did not show any statistical association ( $\mathrm{p}$ $=0.138$ ) (Table-1). Among respondents from group A, $15(57.7 \%)$ were male and $11(42.3 \%)$ were female with a male to female ratio of $1.36: 1$. Among respondents 
from group B, 14 (51.9\%) were male and $13(48.1 \%)$ were female with a male to female ratio of $1.1: 1$. No statistical association $(p=0.584)$ based on sex was found. At baseline, mean BMI of group A patients was
$23.27 \mathrm{~kg} / \mathrm{m} 2$ and mean BMI of group B patients was $23.03 \mathrm{~kg} / \mathrm{m} 2$. After 6 months follow-up, BMI of group A patients increased by $1.63 \%$ and BMI of group B patients increased by $6.6 \%$.

Table-1: Distribution of study population according to Age, Sex and BMI (n=54)

\begin{tabular}{|c|c|c|c|}
\hline Criteria & Group A $(n=26)$ & Group B $(n=27)$ & Significance (P Value) \\
\hline \multicolumn{4}{|l|}{ Age Group } \\
\hline$<20$ Years & $0(0.0 \%)$ & $4(14.8 \%)$ & \\
\hline $21-30$ Years & $11(40.7 \%)$ & $6(22.2 \%)$ & \multirow[t]{2}{*}{$0.138^{\mathrm{a}}$} \\
\hline $31-40$ Years & $11(40.7 \%)$ & $12(44.4 \%)$ & \\
\hline$>40$ Years & $5(18.5 \%)$ & $5(18.5 \%)$ & \\
\hline \multicolumn{4}{|l|}{ Sex } \\
\hline Male & $15(57.7 \%)$ & $14(51.9 \%)$ & \multirow[t]{2}{*}{$0.584^{b}$} \\
\hline Female & $11(42.3 \%)$ & $13(48.1 \%)$ & \\
\hline \multicolumn{4}{|c|}{ BMI (Expressed in Mean \pm SD) } \\
\hline $\begin{array}{l}\text { Baseline } \\
\text { (At the start of the study) }\end{array}$ & $23.27 \pm 1.63$ & $23.03 \pm 1.83$ & $0.603^{\mathrm{a}}$ \\
\hline $\begin{array}{l}\text { At 1st follow up } \\
\text { (at the end of } 1 \text { st month) }\end{array}$ & $23.42 \pm 1.81$ & $23.32 \pm 1.53$ & $0.831^{\mathrm{a}}$ \\
\hline $\begin{array}{l}\text { At 2nd follow up } \\
\text { (at the end of 3rd month) }\end{array}$ & $23.40 \pm 1.88$ & $24.01 \pm 1.52$ & $0.196^{\mathrm{a}}$ \\
\hline $\begin{array}{l}\text { At 3rd follow up } \\
\text { (at the end of } 6 \text { th month) }\end{array}$ & $23.65 \pm 2.03$ & $24.55 \pm 1.57$ & $0.074^{\mathrm{a}}$ \\
\hline
\end{tabular}

\section{At the start of the study, mean urinary total protein (UTP) of group a patients was}

$2.31 \mathrm{gm} / 24 \mathrm{~h}$ and mean UTP of group B patients was $2.63 \mathrm{gm} / 24 \mathrm{~h}$ (Table 2). After 6 months follow-up, UTP of group A patients decreased by $71.86 \%$ and UTP of group B patients decreased by $78.33 \%$. At the start of the study, mean serum creatinine of group A patients was $1.31 \mathrm{mg} / \mathrm{dl}$ and mean serum creatinine of group B patients was $1.34 \mathrm{mg} / \mathrm{dl}$. After 6 months follow-up, serum creatinine of group A patients decreased by $14.50 \%$ and serum creatinine of group B patients decreased by $17.91 \%$. At the start of the study, mean eGFR of group A patients was 64.01 $\mathrm{ml} / \mathrm{min} / 1.73 \mathrm{~m}^{2}$ and mean eGFR of group B patients was 61.37 (SD 9.24) $\mathrm{ml} / \mathrm{min} / 1.73 \mathrm{~m}^{2}$. After 6 months followup, eGFR of group A patients increased by $19.33 \%$ and
eGFR of group B patients increased by $25.44 \%$. At the start of the study, mean total cholesterol (TC) of group A was $185.26 \mathrm{mg} / \mathrm{dl}$ and of group B was $190.22 \mathrm{mg} / \mathrm{dl}$. After 6 months follow-up, mean TC of group A patients increased by $6.37 \%$ and mean TC of group B patients increased by $2.65 \%$. At the start of the study, mean triglyceride (TG) of group A was $163.11 \mathrm{mg} / \mathrm{dl}$ and of group B was $164.41 \mathrm{mg} / \mathrm{dl}$. After 6 months follow- up, mean TG of group A patients decreased by $17.39 \%$ and mean TG of group B patients decreased by $8.18 \%$. At the start of the study, mean serum albumin of group A patients was $31.37 \mathrm{gm} / \mathrm{dl}$ and mean serum albumin of group B patients was $30.76 \mathrm{gm} / \mathrm{dl}$. After 6 months follow-up, serum albumin of group A patients increased by $13.45 \%$ and serum albumin of group B patients increased by $17.26 \%$. 
Table-2: Distribution of study population according to bio chemical profile

\begin{tabular}{|c|c|c|c|}
\hline Criteria & Group A $(n=27)$ & Group B $(\mathbf{n}=27)$ & Significance (P Value) \\
\hline \multicolumn{4}{|c|}{ Urinary Total Protein $(\mathrm{gm} / 24 \mathrm{~h})$} \\
\hline $\begin{array}{l}\text { Baseline } \\
\text { (At the start of the study) }\end{array}$ & $2.31 \pm 0.65$ & $2.63 \pm 0.58$ & $0.070^{\mathrm{a}}$ \\
\hline $\begin{array}{l}\text { At 1st follow up } \\
\text { (at the end of 1st month) }\end{array}$ & $1.75 \pm 0.60$ & $1.81 \pm 0.56$ & $0.708^{\mathrm{a}}$ \\
\hline $\begin{array}{l}\text { At } 2 \text { nd follow up } \\
\text { (at the end of 3rd month) }\end{array}$ & $0.99 \pm 0.46$ & $1.00 \pm 0.50$ & $0.933^{\mathrm{a}}$ \\
\hline $\begin{array}{l}\text { At 3rd follow up } \\
\text { (at the end of 6th month) }\end{array}$ & $0.65 \pm 0.46$ & $0.57 \pm 0.43$ & $0.475^{\mathrm{a}}$ \\
\hline \multicolumn{4}{|l|}{ Serum Creatinine (mg/dl) } \\
\hline Baseline & $1.31 \pm 0.14$ & $1.34 \pm 0.14$ & $0.434^{\mathrm{a}}$ \\
\hline \multicolumn{4}{|l|}{ (At the start of the study) } \\
\hline $\begin{array}{l}\text { At 1st follow up } \\
\text { (at the end of 1st month) }\end{array}$ & $1.20 \pm 0.06$ & $1.22 \pm 0.12$ & $0.600^{\mathrm{a}}$ \\
\hline $\begin{array}{l}\text { At 2nd follow up } \\
\text { (at the end of 3rd month) }\end{array}$ & $1.15 \pm 0.07$ & $1.14 \pm 0.10$ & $0.750^{\mathrm{a}}$ \\
\hline $\begin{array}{l}\text { At 3rd follow up } \\
\text { (at the end of 6th month) }\end{array}$ & $1.12 \pm 1.90$ & $1.10 \pm 0.11$ & $0.299^{\mathrm{a}}$ \\
\hline \multicolumn{4}{|l|}{ eGFR (ml/min/1.73m²) } \\
\hline $\begin{array}{l}\text { Baseline } \\
\text { (At the start of the study) }\end{array}$ & $64.01 \pm 11.44$ & $61.37 \pm 9.24$ & $0.356^{\mathrm{a}}$ \\
\hline $\begin{array}{l}\text { At 1st follow up } \\
\text { (at the end of 1st month) }\end{array}$ & $69.50 \pm 10.80$ & $66.21 \pm 10.82$ & $0.268^{\mathrm{a}}$ \\
\hline $\begin{array}{l}\text { At } 2 \text { nd follow up } \\
\text { (at the end of 3rd month) }\end{array}$ & $70.15 \pm 16.66$ & $71.91 \pm 9.50$ & $0.635^{\mathrm{a}}$ \\
\hline $\begin{array}{l}\text { At 3rd follow up } \\
\text { (at the end of } 6 \text { th month) }\end{array}$ & $76.38 \pm 11.36$ & $76.98 \pm 11.85$ & $0.850^{\mathrm{a}}$ \\
\hline \multicolumn{4}{|l|}{ Total Cholesterol (mg/dl) } \\
\hline $\begin{array}{l}\text { Baseline } \\
\text { (At the start of the study) }\end{array}$ & $185.26 \pm 28.17$ & $190.22 \pm 30.88$ & $0.540^{\mathrm{a}}$ \\
\hline $\begin{array}{l}\text { At 1st follow up } \\
\text { (at the end of 1st month) }\end{array}$ & $189.15 \pm 29.11$ & $187.33 \pm 24.75$ & $0.806^{\mathrm{a}}$ \\
\hline $\begin{array}{l}\text { At 2nd follow up } \\
\text { (at the end of 3rd month) }\end{array}$ & $193.81 \pm 30.90$ & $189.15 \pm 23.87$ & $0.537^{\mathrm{a}}$ \\
\hline $\begin{array}{l}\text { At 3rd follow up } \\
\text { (at the end of 6th month) }\end{array}$ & $197.07 \pm 34.13$ & $195.26 \pm 28.11$ & $0.832^{\mathrm{a}}$ \\
\hline \multicolumn{4}{|l|}{ Triglyceride (mg/dl) } \\
\hline $\begin{array}{l}\text { Baseline } \\
\text { (At the start of the study) }\end{array}$ & $163.11 \pm 42.73$ & $164.41 \pm 44.56$ & $0.467^{\mathrm{a}}$ \\
\hline $\begin{array}{l}\text { At 1st follow up } \\
\text { (at the end of 1st month) }\end{array}$ & $145.81 \pm 40.82$ & $139.15 \pm 24.51$ & $0.717^{\mathrm{a}}$ \\
\hline $\begin{array}{l}\text { At 2nd follow up } \\
\text { (at the end of 3rd month) }\end{array}$ & $138.89 \pm 33.74$ & $145.37 \pm 25.86$ & $0.049^{\mathrm{a}}$ \\
\hline $\begin{array}{l}\text { At 3rd follow up } \\
\text { (at the end of } 6 \text { th month) }\end{array}$ & $134.74 \pm 34.74$ & $150.96 \pm 27.50$ & $0.063^{\mathrm{a}}$ \\
\hline \multicolumn{4}{|l|}{ Serum Albumin (gm/dl) } \\
\hline $\begin{array}{l}\text { Baseline } \\
\text { (At the start of the study) }\end{array}$ & $31.37 \pm 3.05$ & $30.76 \pm 2.82$ & $0.448^{\mathrm{a}}$ \\
\hline $\begin{array}{l}\text { At 1st follow up } \\
\text { (at the end of 1st month) }\end{array}$ & $33.33 \pm 2.60$ & $32.81 \pm 4.07$ & $0.579^{\mathrm{a}}$ \\
\hline $\begin{array}{l}\text { At } 2 \text { nd follow up } \\
\text { (at the end of 3rd month) }\end{array}$ & $34.72 \pm 2.49$ & $33.89 \pm 2.31$ & $0.208^{\mathrm{a}}$ \\
\hline $\begin{array}{l}\text { At 3rd follow up } \\
\text { (at the end of 6th month) }\end{array}$ & $35.59 \pm 2.71$ & $36.07 \pm 2.80$ & $0.523^{\mathrm{a}}$ \\
\hline
\end{tabular}

a = Unpaired t-test, Group A = Mycophenolate Mofetil + Low Dose Prednisolone Group B = Full Dose Prednisolone, Data were expressed in Mean \pm SD 
During the 6 months study period, respondents from both group A and B developed adverse effects of the treatment (Figure-1). Most frequent adverse effect in group A was infection (23\%), followed by diarrhoea (19\%). In group B most frequent adverse effect observed Cushing's syndrome (33\%) followed by new onset Diabetes Mellitus (15\%) and impaired glucose tolerance $(11 \%)$. Outcome of the treatment on both groups were monitored (Figure-2). In group A $38.46 \%$ patients had complete remission, $42.31 \%$ had partial remission and $19.23 \%$ had no remission. In group $\mathrm{B}$, $40.74 \%$ had complete remission, $40.74 \%$ had partial remission and $18.52 \%$ had no remission. There was no statistically significant difference in remission rate between two groups.

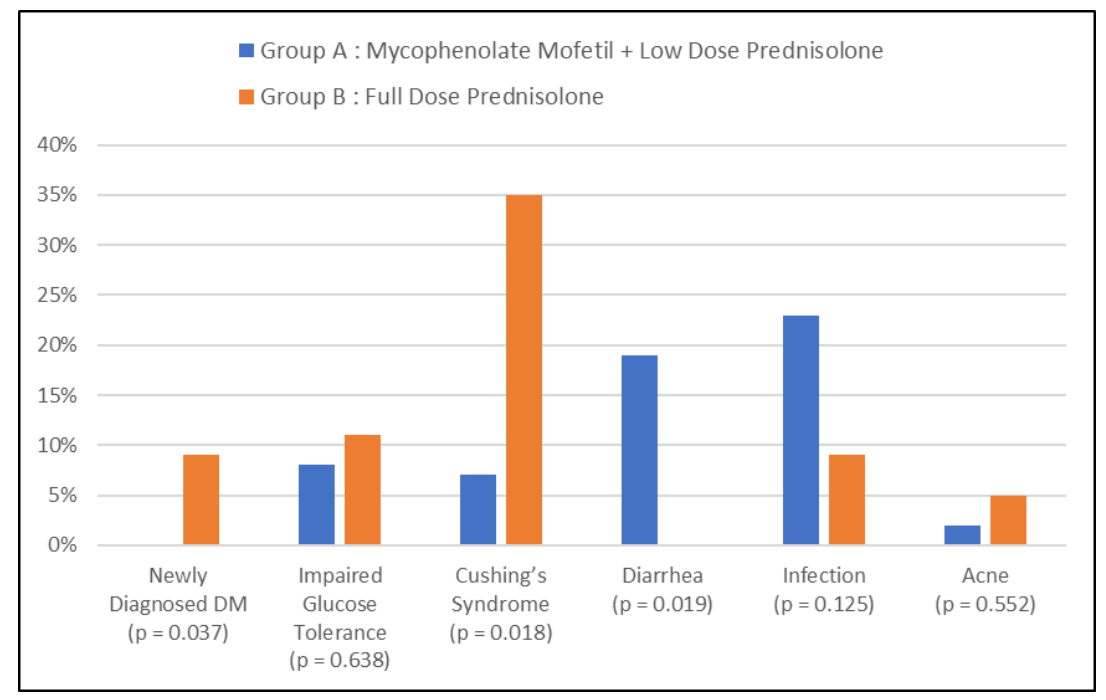

Fig-1: Adverse Effects Observed Between Study Groups during Clinical Trial

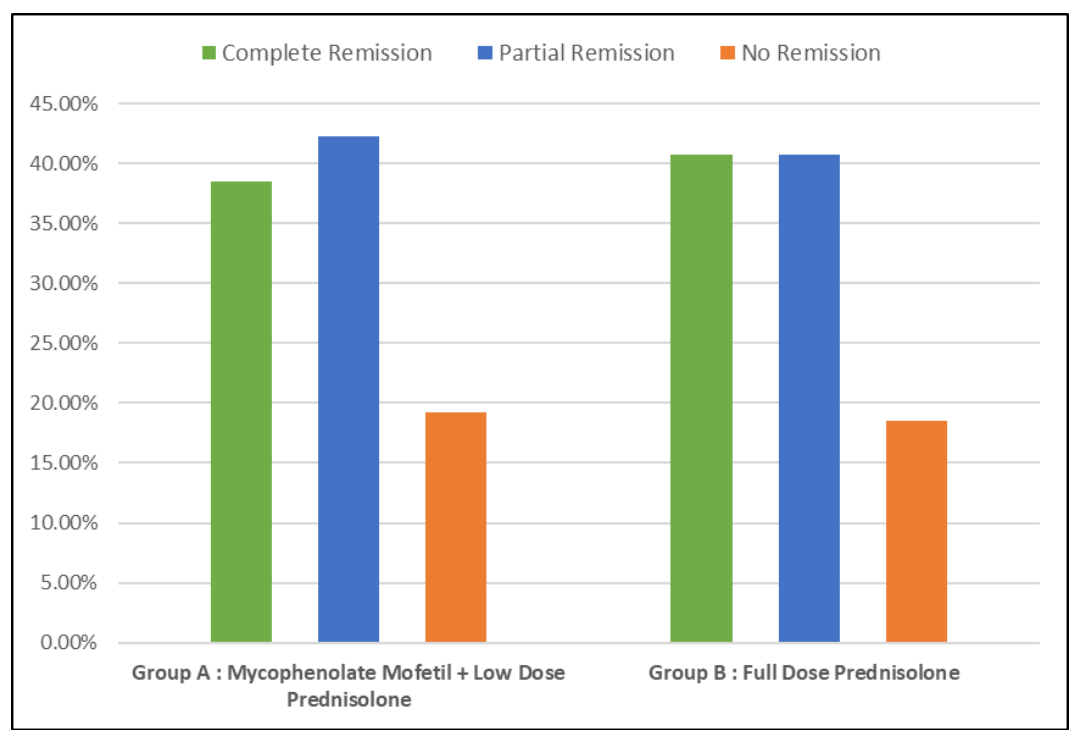

Fig-2: Remission status observed between study groups at the end of the clinical trial

\section{DISCUSSION}

To our knowledge, this study was the first RCT to compare the efficacy and safety of mycophenolate mofetil combined with low dose prednisolone versus standard dose of prednisolone in the treatment of IgA nephropathy among patients from Bangabandhu Sheikh Mujib Medical University. IgAN can be potentially reversible by using immunosuppressive treatment or become chronic and unresponsive to treatments. In this study when the respondents from both group A and B were compared, no statistically significant difference in response rate between two groups was observed. Other studies have compared the efficacy and safety of mycophenolate mofetil combined with low dose prednisolone versus standard dose of prednisolone for therapeutic purpose, but no significant difference have been seen in the overall response rate in any of them [22-24]. Mean age was 33.67 years and 33.44 years respectively for group A and group B and 33.56 years for the whole study population. Previous studies such as ours have shown mean age for study population to be 32.5 years [22], which is consistent with presenting study. Other studies have shown IgA nephropathy to be more common in $3^{\text {rd }}$ 
and $4^{\text {th }}$ decade of life [25-27], which also supports the findings of presenting study.

Male to female ration in this study was $1.2: 1$, making IgA nephropathy a male predominant disease among our study population. Previous studies have also reported IgA nephropathy to be a male predominant disease [25-29]. Mean urinary total protein (UTP) was found to be $2.47 \mathrm{gm} /$ day for the study population at the beginning of the study. Most $\operatorname{Ig}$ A nephropathy patients presented with sub-nephrotic proteinuria. A baseline mean UTP was shown to be $2.37 \mathrm{gm} /$ day among patients with IgA nephropathy [22] and 2.7 gm/day among patients with IgA nephropathy [30], which corresponds with the findings of this study. In the present study, among respondents from group A, complete remission was achieved in $38.46 \%$, partial remission was achieved in $42.31 \%$ and no remission was achieved in $19.23 \%$ of the respondents. In a multicenter randomized controlled trial, 176 patients with $\operatorname{IgA}$ nephropathy were treated with similar regimen of MMF and low dose prednisolone [22]. They reported complete remission in $37 \%$, partial remission in $39 \%$ and no remission in $24 \%$ patients. So, response rate seems to be similar among these studies.

Among respondents from group B, complete remission was achieved in $40.74 \%$, partial remission was achieved in $40.74 \%$ and no remission was achieved in $18.5 \%$ of the respondents. A 2009 study treated IgA nephropathy patients with similar regimen of prednisolone and reported a remission of proteinuria to $<1 \mathrm{gm} /$ day in $75 \%$ of patients and progression of renal disease was observed in none of the patients with $24-\mathrm{h}$ proteinuria <1 gm/day [26]. Another study reported $38 \%$ complete response and $43 \%$ partial response with similar dose of prednisolone for six months [22]. These study findings are consistent with presenting study findings. No significant difference was found in the efficacy and safety of mycophenolate mofetil combined with low dose prednisolone versus standard dose of prednisolone in the treatment of IgA nephropathy, but difference was observed in the adverse effects. Among respondents from group A impaired glucose tolerance was developed in $8 \%$ of the respondents, Cushing's syndrome in $7 \%$, diarrhea in $19 \%$, infection in $23 \%$ and acne in $2 \%$ respondents. Among respondents from group B newly diagnosed DM was in $9 \%$, impaired glucose tolerance was in $11 \%$, Cushing's syndrome in $35 \%$, infection in $9 \%$ and acne was in $5 \%$ of the respondents; showing a clear distinction in the development and progression of adverse effects between the two groups. Similar trend was shown in a 2007 study [22], where the group receiving mycophenolate mofetil combined with low dose prednisolone developed newly diagnosed diabetes mellitus in $1 \%$, impaired glucose tolerance in $14 \%$, Cushing's syndrome in $18 \%$, diarrhea in $8 \%$, infection in $31 \%$ and acne in $2 \%$ of the respondents and the group receiving normal dose of prednisolone regimen, developed newly diagnosed DM in $14 \%$, impaired glucose tolerance in $17 \%$, Cushing's syndrome in $48 \%$, diarrhea in $11 \%$, infection in $23 \%$ and acne in $6 \%$ of the respondents. These findings corroborate with presenting study findings.

\section{CONCLUSION}

Mycophenolate mofetil and low-dose prednisone combined therapy is a reasonable treatment choice for IgA nephropathy, which doesn't show any significant improvement in recovery rate over regular dose of prednisolone. But there were fewer cases of impaired glucose tolerance and Cushing's syndrome, but higher incidence of diarrhea among patients treated with MMF and low dose of prednisolone, than patients only treated with regular dose of prednisolone.

\section{LIMITATIONS}

This study was an open-label single centre trial on limited number of patients on a short duration of six months.

\section{RECOMMENDATION}

A larger multi-centre trial with longer followup time is recommended to establish the long-term efficacy and safety of MMF combined with low dose prednisolone in patients with IgA nephropathy.

\section{REFERENCES}

1. Rodrigues JC, Haas M, Reich HN. IgA nephropathy. Clinical Journal of the American Society of Nephrology. 2017 Apr 3;12(4):677-86.

2. Schena FP, Nistor I. Epidemiology of IgA nephropathy: a global perspective. InSeminars in nephrology 2018 Sep 1 (Vol. 38, No. 5, pp. 435 442). WB Saunders.

3. Woo KT, Chan CM, Mooi CY, L-Choong H, Tan HK, Foo M, Lee GS, Anantharaman V, Lim CH, Tan CC, Lee EJ. The changing pattern of primary glomerulonephritis in Singapore and other countries over the past 3 decades. Clinical nephrology. 2010 Nov 1;74(5):372-83.

4. Canetta PA, Kiryluk K, Appel GB. Glomerular diseases: emerging tests and therapies for IgA nephropathy. Clinical Journal of the American Society of Nephrology. 2014 Mar 7;9(3):617-25.

5. Barbour SJ, Reich HN. Risk stratification of patients with IgA nephropathy. American Journal of Kidney Diseases. 2012 Jun 1;59(6):865-73.

6. Liu H, Peng Y, Liu H, Liu Y, Yuan S, Liu F, Yang D, Chen X, He L, Fu M, Shao J. Renal biopsy findings of patients presenting with isolated hematuria: disease associations. American journal of nephrology. 2012;36(4):377-85.

7. Li PK, Ho KK, Szeto CC, Yu L, Lai FM. Prognostic indicators of $\operatorname{IgA}$ nephropathy in the Chinese-clinical and pathological perspectives. Nephrology Dialysis Transplantation. 2002 Jan 1;17(1):64-9. 
8. Le W, Liang S, Hu Y, Deng K, Bao H, Zeng C, Liu Z. Long-term renal survival and related risk factors in patients with $\operatorname{IgA}$ nephropathy: results from a cohort of 1155 cases in a Chinese adult population. Nephrology Dialysis Transplantation. 2012 Apr 1;27(4):1479-85.

9. Lai KN. Pathogenesis of IgA nephropathy. Nature Reviews Nephrology. 2012 May;8(5):275-283.

10. Floege J, Feehally J. IgA nephropathy: recent developments. Journal of the American Society of Nephrology. 2000 Dec 1;11(12):2395-403.

11. Abe T, Kida H, Yoshimura M, Yokoyama $H$, Koshino Y, Tomosugi N, Hattori N. Participation of extracapillary lesions (ECL) in progression of IgA nephropathy. Clinical nephrology. 1986 Jan $1 ; 25(1): 37-41$.

12. of the International AW, Network IN, Roberts IS, Cook HT, Troyanov S, Alpers CE, Amore A, Barratt J, Berthoux F, Bonsib S, Bruijn JA. The Oxford classification of IgA nephropathy: pathology definitions, correlations, and reproducibility. Kidney international. 2009 Sep 1;76(5):546-56.

13. Palevsky PM, Liu KD, Brophy PD, Chawla LS, Parikh CR, Thakar CV, Tolwani AJ, Waikar SS, Weisbord SD. KDOQI US commentary on the 2012 KDIGO clinical practice guideline for acute kidney injury. American Journal of Kidney Diseases. 2013 May 1;61(5):649-72.

14. Nowack R, Birck R, van der Woude FJ. Mycophenolate mofetil for systemic vasculitis and IgA nephropathy. The Lancet. 1997 Mar 15;349(9054):774.

15. Choi MJ, Eustace JA, Gimenez LF, Atta MG, Scheel PJ, Sothinathan R, Briggs WA. Mycophenolate mofetil treatment for primary glomerular diseases. Kidney international. 2002 Mar 1;61(3):1098-114.

16. Allison AC, Eugui EM. Mycophenolate mofetil and its mechanisms of action. Immunopharmacology. 2000 May 1;47(2-3):85118.

17. Allison AC, Eugui EM. Purine metabolism and immunosuppressive effects of mycophenolate mofetil (MMF). Clinical transplantation. 1996 Feb 1;10(1 Pt 2):77-84.

18. Sollinger HW. Mycophenolate mofetil for the prevention of acute rejection in primary cadaveric renal allograft recipients. US Renal Transplant Mycophenolate Mofetil Study Group. Transplantation. 1995 Aug 1;60(3):225-32.

19. Chan TM, Li FK, Tang CS, Wong RW, Fang GX, Ji YL, Lau CS, Wong AK, Tong MK, Chan KW, Lai KN. Efficacy of mycophenolate mofetil in patients with diffuse proliferative lupus nephritis. New England Journal of Medicine. 2000 Oct 19;343(16):1156-62.

20. Fujihara CK, Malheiros DM, Zatz R, de Lourdes
Noronha I. Mycophenolate mofetil attenuates renal injury in the rat remnant kidney. Kidney international. 1998 Nov 1;54(5):1510-9.

21. Romero F, Rodríguez-Iturbe B, Parra G, González L, Herrera-Acosta J, Tapia E. Mycophenolate mofetil prevents the progressive renal failure induced by $5 / 6$ renal ablation in rats. Kidney international. 1999 Mar 1;55(3):945-55.

22. Hou JH, Le WB, Chen N, Wang WM, Liu ZS, Liu D, Chen JH, Tian J, Fu P, Hu ZX, Zeng CH. Mycophenolate mofetil combined with prednisone versus full-dose prednisone in IgA nephropathy with active proliferative lesions: a randomized controlled trial. American Journal of Kidney Diseases. 2017 Jun 1;69(6):788-95.

23. Lu Z, Song J, Mao J, Xia Y, Wang C. Evaluation of mycophenolate mofetil and low-dose steroid combined therapy in moderately severe HenochSchönlein purpura nephritis. Medical science monitor: international medical journal of experimental and clinical research. 2017;23:2333.

24. Li X, Tian J, Wu J, He Q, Li H, Han F, Li Q, Chen Y, Ni Q, Chen J. A comparison of a standard-dose prednisone regimen and mycophenolate mofetil combined with a lower prednisone dose in Chinese adults with idiopathic nephrotic syndrome who were carriers of hepatitis B surface antigen: a prospective cohort study. Clinical therapeutics. 2009 Apr 1;31(4):741-50.

25. Pozzi C, Bolasco P, Fogazzi G, Andrulli S, Altieri P, Ponticelli C, Locatelli F. Corticosteroids in IgA nephropathy: a randomised controlled trial. The Lancet. 1999 Mar 13;353(9156):883-7.

26. Manno C, Torres DD, Rossini M, Pesce F, Schena FP. Randomized controlled clinical trial of corticosteroids plus ACE-inhibitors with long-term follow-up in proteinuric $\operatorname{IgA}$ nephropathy. Nephrology Dialysis Transplantation. 2009 Dec 1;24(12):3694-701.

27. Siddappa S, Kowsalya R, Mythri KM. IgA nephropathy in a tertiary care center from south India. Indian journal of nephrology. 2011 Oct;21(4):230-234.

28. Prakash S, Kanjanabuch T, Austin PC, Croxford R, Hsu CY, Choi AI, Cattran DC. Continental variations in IgA nephropathy among Asians. Clinical nephrology. 2008 Nov;70(5):377-384.

29. Hall YN, Fuentes EF, Chertow GM, Olson JL. Race/ethnicity and disease severity in IgA nephropathy. BMC nephrology. 2004 Dec;5(1):16.

30. Frisch G, Lin J, Rosenstock J, Markowitz G, D'agati V, Radhakrishnan J, Preddie D, Crew J, Valeri A, Appel G. Mycophenolate mofetil (MMF) vs placebo in patients with moderately advanced IgA nephropathy: a double-blind randomized controlled trial. Nephrology Dialysis Transplantation. 2005 Oct 1;20(10):2139-45. 